\title{
An Exploration of the Effectiveness of School Leadership Training in Ethiopian Public Universities: Intentions, Practices and Challenges
}

\author{
Tadesse Regassa Mamo ${ }^{1} \&$ Adula Bekele ${ }^{2} \&$ Dereje Daksa ${ }^{3}$
}

\author{
${ }^{1 \& 3}$ Department of Educational Planning and Management, Jimma University, Ethiopia \\ ${ }^{2}$ Department of Teacher Education and Curriculum Studies, Jimma University, Ethiopia \\ Correspondence: Tadesse Regassa Mamo, Jimma University, Ethiopia. \\ Email: tadesse.regassa@ju.edu.et
}

Received: July 14, $2019 \quad$ Accepted: August 27, $2019 \quad$ Online Published: September 1, 2019

doi: 10.23918/ijsses.v6i1p96

\begin{abstract}
The primary intention of this study was to examine the practices of school leadership and leadership development from the views of stakeholders. The study employed a cross-section survey research method as this enables to assess the issue in its natural setting. The data sources for the study were students, teachers, supervisors, principals, TDP core process owners and Woreda and Zone Education Officers. Data were collected through questionnaire, interview and focus group discussions with key stakeholders. Finally, data were categorized and analyzed using frequency, mean score and verbatim. Accordingly, the finding of the study revealed that leadership practices were not participatory, tasks remain in principal offices, teachers are less encouraged to take part in leadership and principal is the sole decision maker. Furthermore, the study result also disclosed that there was no balance between the theoretical knowledge and practical skills in school leadership development. The leadership development either tilted towards the theory or the practical skills whereby the school leadership training was so fragmented like PGDSL, PGCPSS, PGCPS, EDL, EDPM, and ScL programs. Therefore, from this it can be concluded that leadership succession was one of the future challenges of identifying and recruiting school leaders. Hence, for better school leadership development and to get the best out of it, the education offices at various echelons need to create a well-organized and comprehensive training program unlike the current fragmented approaches of leadership development practices.
\end{abstract}

Keywords: School Leadership, Intentions, Leadership Practices, Teacher Development

\section{The Problem Statement}

The 1994 education and training policy of Ethiopia have resulted in structural and conceptual changes at all levels of the education system. The major structural changes according to Dawit (2008) include the completion of general secondary education at Grade 10; the opening of higher education preparatory programs at Grades 11 and 12; the shortening of bachelor programs from 4 years to three; and the use of different mother tongue languages as the medium of instruction in primary schools. Therefore, the education sector has experienced a significant number of new regulations and structuring (Dawit, 2008).

Ministry of education (2003) has stated that the introduction of TESO program as a government initiated reform in 2003 was meant for addressing the serious problems present in the education system so as to realize the aims of the education and training policy. For the first time, a donor-supported Teacher Development Program to provide universal primary education by 2015 and improving the quality of primary and secondary education was realized in Ethiopia (UNESCO, 2005). One of the major changes 
that TESO initiated was that there must be a strong partnership between school leadership training institutions (universities) and schools with adequate field experience for student teachers (Dawit, 2008). On top of these, the reform is also mandated that active learning methods will be employed in teacher education and CPD will be implemented where school leadership has to be designed from this perspective.

However, later on Dawit (2008) made a comprehensive study to evaluate the implementation of TESO program and the finding showed that: TESO did not addressed the school reality; except the allocation of longer duration, TESO did not bring change in instructional skills of leaders; practicum program is not supported by prospective leader reflection; students do not engage in longer practice sessions because it is found not to be viable for economic reasons and shortage of time; trainees themselves do not have a clear know-how of what to do and what is expected of them when they go for field experience in their first year training; there is no discussion and reflection on what students have got from their experience other than a simple report to be written and corrected by teacher educators; teachers and leaders in high schools are not clear about their role in monitoring the school leadership training program; TESO gave less emphasis to school leadership and management as well.

Besides, there was also a general education quality improvement program (GEQIP) which primarily aimed on enhancing the quality of general education by adapting the concept of the school effectiveness model (World Bank, 2008). The education sector reform implemented by the Ethiopian government has established a fertile ground for the inception of general education quality improvement programs at all levels of the education sectors effectively (MoE, 2009).

However, the effective implementation of the program depends on efficient coordination mechanisms; proper resource management and procurement practices and the timely implementation and effective monitoring of the overall project outcomes which is mainly role given to school leaders. The GEQIP provides the necessary resources for the effective coordination and monitoring and evaluation, and the implementation of an information and communication strategy at the national and regional levels (World Bank, 2008). It was incognizant of these that MoE has tried all its best to reform the school leadership preparation program (SCL/EDL/PGDSL), the school leadership and management including supervision (PGCPSS/PGCPS) and attempt to enhance the information and communication technology facility in school leadership training public universities.

According to World Bank (2008) despite the expansion of trainees enrollment and all concerted efforts to enhance the ability and skill of school leaders, it was found out that majority of the leadership candidates did not identify the school leadership profession as their preferred career. Hence, the quality is so weak due to shortage of teaching materials in universities, didactic teaching methods, inadequacy of practice teaching and an insufficient support for candidates/poor leadership and supervisory support (World Bank, 2008). To alleviate all these problems, it was recommended that intake and selection of prospective leaders has to be revised, school leadership and management has to be strengthened, and supervision practice needs to be revised and leaders training institutions should be equipped with the necessary infrastructure and ICT facilities.

In addition to the teacher training program, GEQIP has introduced one of the key reforms in school leadership and management. It has been recognized that without improving school leadership, it was 
impossible to realize quality education just only by training teachers. In line with this, UNESCO (1999), Lemlem (2010) indicated that developing and building leadership practices are significant for individual teachers' professional development, school improvement and satisfaction of public demands. To this end, school leadership and management should be well planned and organized to accommodate the central interest of teachers, students and the society at large.

\subsection{Statement of the Problem}

School leadership is a critical human resources issue having a variety of functions. The function involves diverse and demanding functions such as setting direction, managing teaching and learning, developing people (teachers and students) within a professional learning community, and developing the organization (Mulu, 2012; Leithwood et al., 2006). The skills, qualifications and personal attributes required of school managers (head teachers/principals/directors, deputy heads, subject and year heads) are therefore multiple and varied. Although traditionally school leadership has been drawn from the ranks of experienced teachers, head teachers and other managers need management training, appraisal and continuing professional development opportunities in order to provide classroom teachers with the support and guidance they need. They also need support from administrative staff so they can focus on teacher management and support, rather than administrative duties.

The Ethiopian ministry of education has launched the General Education Quality Improvement Program (GEQIP) a multi donor trust fund meant to enhance the quality of general education (MoE). One of the pillars of GEQIP was to significantly increase the capacity of education managers in Ethiopia. Besides, ESDP IV and GTP I and II also gave due attention to promote quality of education by designing and implementing a vibrant school leadership preparation program. But, on meeting, educational conference, educational reports and felid and classroom experiences show that the current school leadership training program is not free from complaints.

In a similar fashion, one analysis has suggested that in certain countries head teachers, middle managers, supervisors and local education officials are often promoted from classroom teaching into school management positions with little organized training. Teachers are commonly selected for management positions on the grounds of length of service rather than aptitude. They may even be taken out of classroom teaching and given supervisory duties because of a lack of aptitude. Head teachers may not be trained in or aware of equal opportunities principles, leading to discrimination based on gender, ethnicity, and disability or HIV status. Head teachers may be sometimes favor male teachers over female teachers when they need someone to deputies for them or take on sought after duties, and are reported to be more likely to believe male teachers in disputes between teachers, including those involving sexual harassment by male teachers (GCE, 2006).

On top of these, various studies made by PGDT and PGDSL training universities have come up with the following gaps: trainees lack of understanding and interest on the program; trainees were meant to practice in schools but in actual situation the program is implemented in summer where schools are off duty; those PGDSL trainees are not interested to stay in the program since they have the chance to get their bachelor degree instead of wasting their time on this training; absence of separate arrangement between primary and secondary school leaders; school leadership training program did not addressed the needs of the 
trainees and education bureaus; stakeholders have no equal understanding on the intentions of school leadership training programs; improper recruitment and placement of school leadership trainees is frequently observed; although PGDSL trainees should have been given adequate learning support during the workplace-based phase, this has never been practiced; above all, as far as I know this is one of the least researched areas in the Ethiopian Education System. Even most of the few studies done in the area focused on the conventional school leadership program.

Therefore, these are some of the pressing issues that demands research in order to come up with feasible, possible and potential solutions that triggered this study to be conducted on the areas of school leadership. Assessing, evaluating communicating and enhancing the intention, practice and minimizing challenges related to school leadership is a vitally important activity for HEIs and all other stakeholders in order to be responsive to the needs of the educational goals in general and beneficiaries in particular. In order to realize this, the following basic question got due attention:

- What are the practices, concerns and outstanding issues in the preparation of school leaders in Ethiopia?

- To what extent the intention and practice of school leadership training are aligned?

- To what extent the candidates in the system are fulfilling the required criteria set by MoE?

- How far do the responsible bodies at various levels come on board to strengthen the program?

\subsection{The Specific Objectives of This Study Will Be}

- To assess the extent to which school leadership and management training is need based

- To investigate the perception of PGDSL trainees towards the intention and implementation of the program

- To identify the gap between the intension of PGDSL and the actual practices

- To explore the level of school leaders' professional commitment to improve school

- To identify and enhance the missing or inadequately addressed issues in preparing school leadership and management

\subsection{Delimitation of the Study}

It is essential to delimit the boundary of the study both geographically and conceptually to maintain the manageability of the study. Had it been possible to include all the universities, it would have been better to make the study more comprehensive. However, due to time and resource limitation and to make the study within the reach of the researcher some senior universities were treated. Accordingly, the study involved four of the major universities which took part in the training of school leaders, namely Jimma University, Mekele University, Hwassa University and Addis Ababa University. These universities are selected by the federal ministry of education to deliver the new school leadership training namely postgraduate diploma in school leadership (PGDSL), school leadership (SCL) and supervisors. The study was conceptually delimited to exploration of the issues related to selection, preparation/training, utilization and challenges related to the current mode of training school leadership. It will not deal with their performance in schools, their relation with teachers and the community at large. 


\section{Research Design and Method}

\subsection{Research Design}

As defined by Malhotra (2007) and Creswell (2006), a research design is an overall framework of a research that explains the direction and method to be used in the study to formulate the basic research question, to gather the information needed either from primary or secondary sources, to make the analysis and draw conclusions and recommendations. By considering the theoretical perspective of claiming knowledge (pragmatic approach), the procedures followed to conduct the study and the methods of data collection and analysis used was a mixed method approach which was assumed to be appropriate for this study. Besides, it is also one of the most common designs of research in social and human sciences (Tashakkori \& Teddlie, 1998). Therefore, of the various techniques of mixing method approach, the triangulation design was employed.

\subsection{Participants and Data Sources of the Study}

For the present study, trainees, instructors and department heads, were considered as data sources. Besides these, minutes, education reforms, ESDP documents, national and international literatures, higher education proclamations, policy directives, reports and other relevant documents will be critically analyzed to back up the data obtained from the primary sources.

\subsection{Sample and Sampling Technique}

The sampling method in this research involves multistage sampling as it starts from the selection of higher education institutions down to specific respondents. So, sample selection was done at university level, then down to teacher level and finally at student level.

Accordingly, the researcher divided Ethiopian Universities in the four directions as north, south, west and center. Therefore, one university from each direction will be included by using simple random sampling technique to maintain representation. Accordingly, Jimma University from the west, Mekele from the north, Hawassa from south and south east and Addis Ababa from the center were treated as a study sample. Then, stratified simple random sampling technique was employed to select individual respondents from each university for two reasons. First, it gives equal chance for everyone to be selected as a sample. Second, it enables the researcher to take proportional number of sample respondents from each population group. The assumption is that these trainees are found in one department in each of the universities, which is under the department of educational planning and management.

It was believed that years of service and work experience have a paramount role in getting reliable information. Instructors with service years below two were not considered in this study. Besides instructors who are on study leave will also not to be included in the sample respondents. Therefore, those who are active staff members and two or more service years will emphasize in the formation of the sampling frame.

On top of these, key persons working at managerial positions of the education bureaus such heads, directors, deans and core process owners and experts working on educational leadership were purposefully targeted in the sampled universities and regions, because of their prime role in dealing with the issue under study. 


\subsection{Data Collection Tools}

In this study, there were two main ways of collecting the information from people through selfadministered questionnaire and oral (face to face) interview. The rationale behind employing questionnaire for this study emanated from the fact that the study tries to collect information on opinions, attitudes and perceptions of respondents. Besides, a 5-point likert scale was employed as a measurement beginning from $1=$ strongly disagree to $5=$ strongly agree. Basically, a likert scale is a statement presented to respondents to rate the degree to which they agree or disagree with the idea. Hence, an ordinal scale with a 5-point scale involving 5-points was employed in order to rate the agreement or disagreement of respondents.

The most common instrument used for data collection in qualitative research is in-depth interview and document analysis (Berg, 2001; Given, 2008). As a result, these instruments were utilized in this study. The qualitative data were used to supplement the information gathered in quantitative approaches. Besides, pertinent documents such as education policy, rules and regulation and ESDPs were assessed and analyzed to explore the intention of the current school leadership program to compare with practice.

\subsection{Method of Data Analysis}

The data obtained through questionnaire were analyzed using both descriptive (frequency, percentage, mean) and inferential statistics (correlation and regression) respectively. T-test and ANOVA were also used to see opinion difference between/ the students, teachers and education officers. Spearman rank order correlation was employed to identify which factors will affect the leadership training program at universities. Multiple regressions analysis will be employed to determine the predictive role of the identified factors on the leadership program. Moreover, step wise multiple regression analysis will be used to determine the extent of contribution of each independent variable on the dependent variables. Further analysis was made for all five point likert scale measurements based on the following mean score results: 1.00-1.49= Strongly Disagree, 1.50-2.49= Disagree, 2.50-3.49= Moderate, 3.50-4.49= Agree, 4.50-5.00= Strongly Agree

\section{Result and Discussion}

This chapter deals with presentation, analysis and interpretation of the data. The data sources were the first and second PGDSL trainees and trainers. Thus, the data were secured through questionnaires and interviews. A total of 190 copies of questionnaires were distributed to the respondent trainees. Out of those, 84 were filled correctly and returned. Thus, the total return rate of the questionnaires was $77 \%$ of the sample population.

The analysis of quantitative data was computed by SPSS and analyzed using both descriptive (frequency, percentage, mean) and Spearman rank order correlation. The qualitative data gathered through interview and observation were analyzed qualitatively to substantiate the quantitative data. The analyzed data were compiled and organized in a way that suits interpretation of the results in addressing the research questions. In this way five tables were constructed in categorizing the objectives of the study in thematic groups which in details. 


\subsection{General Information of the Respondents}

Understanding about the overview of the respondents' characteristics was important for further analysis of their responses. Hence, attempts were made to describe the background of the respondents which directly or indirectly related to the objectives of the study. Accordingly, the respondents/ trainees and training university, sex, age, work experience, previous field of study, current position, year of services were separately treated.

As indicated in Table 1, the institutional distribution of trainees was found to be 79, 56 and 55 were from Hawasa, Wollega and Jimma University respectively those encompass 420, 315, 120 trainees population consecutively. With regard to sex proportion, females were very few in number compared to their male counter parts where it comprised only 17 (9\%) from 190 (100\%) of the total number of the respondents. This reveals that the participation of females in school leadership is not promising where by the implication is that a lot has to be done to improve the participation of female in school leadership in particular and education sector in general.

Age wise, the majority of the respondents 75 (42\%) were under the age group of 31-40 years old which implies most of the school leaders were young and in productive age capacity. The table also showed that $10(5.3 \%)$ of the trainees were below 2 years work experiences that reveals as they were experienced in schools and it is aligned with MoE guide which invite the program participants above 2 years experience. But still the majority (40\%) of the respondents was having a work experience of 6-10 years. 
Table 1: General Information of the Respondents

\begin{tabular}{|c|c|c|c|}
\hline Items & \multicolumn{3}{|c|}{ Responses (190) } \\
\hline \multirow{5}{*}{ Respondents University } & & No. & $\%$ \\
\hline & Hawassa & 79 & 41.6 \\
\hline & Wollega & 56 & 29.5 \\
\hline & Jimma & 55 & 28.9 \\
\hline & Total & 190 & 100.0 \\
\hline \multirow[t]{3}{*}{ Sex } & Male & 172 & 91.0 \\
\hline & Female & 17 & 9.0 \\
\hline & Total & 189 & 100.0 \\
\hline \multirow[t]{6}{*}{ Age } & Below 20 & 1 & .6 \\
\hline & $20-30$ & 84 & 47.2 \\
\hline & $31-40$ & 75 & 42.1 \\
\hline & $41-50$ & 14 & 7.9 \\
\hline & Above 50 & 4 & 2.2 \\
\hline & Total & 178 & 100.0 \\
\hline \multirow[t]{7}{*}{ Experience } & Below 1 year & 10 & 5.3 \\
\hline & $1-5$ years & 20 & 10.5 \\
\hline & $6-10$ years & 76 & 40.0 \\
\hline & $11-15$ years & 55 & 28.9 \\
\hline & $16-20$ years & 18 & 9.5 \\
\hline & Above 20 years & 11 & 5.8 \\
\hline & Total & 190 & 100.0 \\
\hline \multirow[t]{4}{*}{ Previous field of study } & Natural sciences & 92 & 48.4 \\
\hline & Social sciences & 58 & 30.5 \\
\hline & EdPM & 40 & 21.1 \\
\hline & Total & 100 & 100 \\
\hline \multirow[t]{4}{*}{ Current Position } & School principal & 121 & 63.7 \\
\hline & Supervision & 45 & 23.7 \\
\hline & Teacher & 24 & 12.6 \\
\hline & Total & 190 & \\
\hline \multirow[t]{3}{*}{ Year of study } & 1st Year & 93 & 53.1 \\
\hline & 2nd Year & 82 & 46.9 \\
\hline & Total & 175 & 100.0 \\
\hline
\end{tabular}

Concerning the educational background, in spite of the program entrance criteria $40(21.1 \%)$ of trainees join the program from EdPM background while those from those from other field of study (natural and social sciences) compose $78.9 \%$ of the respondents. Regarding the position from where the trainees come to the program $24(12 \%)$ of the trainees were teachers which is not acceptable as entry criteria. This implies that the relevance of the previous field of study is not to the required level. In Table 1, respondents were asked 
to express the position where they come for the training and they replied that majority $(63.7 \%)$ of them were working on the position of school principal. However, about $23.7 \%$ of the respondents held the position of supervision. From this analysis, one can infer that most of the trainees were working on the position for which they are trained and will work on.

\subsection{Perceptions on the Importance of the Training Program}

In Table 2, there are items prepared to assess how far the respondents identified and recognized the importance and benefits of the current school leadership training program. There are about 19 items dealing with the roles of the program in producing professional school leaders, improve the school performance, promote the vision and mission of the school, need at all levels of the educational administration, capacity to hold more responsibility due to the training in place and capacity of the training to promote the leadership capacity of the school leaders and enhance the effectives of the school. 
Table 2: Trainees Perception on Importance/benefits of the Program

\begin{tabular}{|c|c|c|c|c|c|}
\hline \multicolumn{6}{|c|}{ One-Sample Statistics } \\
\hline & $\mathrm{N}$ & Mean & $\begin{array}{c}\text { Std. } \\
\text { Deviation }\end{array}$ & $\mathrm{t}$ & Sig. (2-tailed) \\
\hline $\begin{array}{l}\text { The training helps me to consider as a } \\
\text { professional leader }\end{array}$ & 190 & 1.34 & .662 & -13.704 & .000 \\
\hline $\begin{array}{l}\text { The training equips me with practical } \\
\text { knowledge \& skill of leading school }\end{array}$ & 190 & 1.46 & .717 & -10.316 & .000 \\
\hline $\begin{array}{l}\text { The training helps me to promote the } \\
\text { vision of the school }\end{array}$ & 189 & 1.40 & .712 & -11.651 & .000 \\
\hline $\begin{array}{l}\text { The training is important regardless of my } \\
\text { current position }\end{array}$ & 189 & 1.53 & .741 & -8.742 & .000 \\
\hline $\begin{array}{l}\text { I am enjoying working with team because } \\
\text { of this training }\end{array}$ & 188 & 1.54 & .726 & -8.635 & .000 \\
\hline $\begin{array}{l}\text { The training helps me to identify core } \\
\text { issues in school }\end{array}$ & 189 & 1.46 & .740 & -10.026 & .000 \\
\hline $\begin{array}{l}\text { I hope I will assume more responsibility } \\
\text { due to this training }\end{array}$ & 189 & 1.49 & .727 & -9.611 & .000 \\
\hline $\begin{array}{l}\text { I feel that this training is to meant to } \\
\text { bring a shift in performance of school }\end{array}$ & 189 & 1.52 & .712 & -9.303 & .000 \\
\hline The program motivates me & 190 & 1.67 & .822 & -5.471 & .000 \\
\hline $\begin{array}{l}\text { I would like to recommend the training } \\
\text { even for others }\end{array}$ & 190 & 1.62 & .772 & -6.764 & .000 \\
\hline $\begin{array}{l}\text { The training has promoted my visible } \\
\text { presence }\end{array}$ & 190 & 1.62 & .786 & -6.647 & .000 \\
\hline The training helps me to be a role model & 190 & 1.58 & .750 & -7.738 & .000 \\
\hline $\begin{array}{l}\text { This training is a kind of program that } \\
\text { makes me a better school leader }\end{array}$ & 190 & 1.68 & 2.258 & -1.960 & .051 \\
\hline $\begin{array}{l}\text { I feel that without taking this training it is } \\
\text { difficult to lead the school }\end{array}$ & 190 & 1.78 & .849 & -3.504 & .001 \\
\hline $\begin{array}{l}\text { The training increase my leadership } \\
\text { effectiveness }\end{array}$ & 190 & 1.52 & .747 & -8.840 & .000 \\
\hline
\end{tabular}

In Table 2 respondents were asked to express their views with regard to the importance and benefits of this school leadership and training program. Item 1 in Table 2 is about how far the training is important to produce professional school leaders. The result reveals that most of the students agreed yes; it will help to produce professional school leaders with a mean value of 1.34 .

From this one can infer that, from its inception the program has a capacity to promote the professionalism of school leadership. So, if moved to the final stages of implementation, the program will help to have not only professional school leaders but also improve the performance of the students. 
Based on the three-point rating scale (Agree $=1$, Neutral $=2$, Dis agree $=3$ ), mean values were compared with the neutral value (2) to examine the trainees perception on the importance of the training. As can be seen from Table 3, the mean value was 1.55 and this shows many of the respondents were not clear of the importance of the program. Because of this, they were not able to decide what to say on the importance of school leadership training and development.

Table 3: One-Sample Statistics

\begin{tabular}{|l|r|r|r|r|rr|}
\hline & $\mathrm{N}$ & Mean & $\begin{array}{c}\text { Std. } \\
\text { Deviation }\end{array}$ & $\mathrm{t}$ & \multicolumn{2}{|c|}{ Sig. (2-tailed) } \\
\hline Importance & 183 & 1.5479 & .58627 & -10.432 & .000 \\
\hline
\end{tabular}

Table 4 is about the intention and actual practices of school leadership program in Ethiopian public universities.

Table 4: Intention and Actual Practices

\begin{tabular}{|l|r|r|r|r|r|}
\hline \multicolumn{7}{|c|}{ One-Sample Statistics } \\
\hline & \multicolumn{1}{|c|}{$\mathrm{N}$} & Mean & $\begin{array}{c}\text { Std. } \\
\text { Deviation }\end{array}$ & $\mathrm{t}$ & $\begin{array}{c}\text { Sig. (2- } \\
\text { tailed) }\end{array}$ \\
\hline $\begin{array}{l}\text { As a trainee I am very willing to attend the } \\
\text { training }\end{array}$ & 189 & 1.51 & .790 & -8.475 & .000 \\
\hline The program is basically demand driven & 189 & 1.69 & .744 & -5.667 & .000 \\
\hline I join the program in my interest & 189 & 1.73 & .848 & -4.374 & .000 \\
\hline $\begin{array}{l}\text { I am able to join the program through stiff } \\
\text { competition }\end{array}$ & 188 & 1.61 & .756 & -7.139 & .000 \\
\hline $\begin{array}{l}\text { I feel that the selection mechanisms brought } \\
\text { the right candidate to the program }\end{array}$ & 190 & 1.65 & .761 & -6.390 & .000 \\
\hline
\end{tabular}

From the output of t-test it can be inferred that the trainees were not clear of what is intended to be achieved by training school leadership this way and how is the program going on. The mean values for all the items were closer to the neutral value and the implication is that respondents were preferred to be neutral towards the intention of the program. The mean value of 1.73 and 1.69 implies the program is less demand driven and joined the program with less interest.

Table 5: One-Sample Statistics

\begin{tabular}{|c|c|c|c|c|c|}
\hline & $\mathrm{N}$ & Mean & $\begin{array}{c}\text { Std. } \\
\text { Deviation }\end{array}$ & $\mathrm{t}$ & $\begin{array}{c}\text { Sig. (2- } \\
\text { tailed) }\end{array}$ \\
\hline Gaps & 186 & 1.6247 & .60879 & -8.407 & .000 \\
\hline
\end{tabular}

In Table 5 t-test analysis was carried out the check the opinion difference among the respondents with regard to intention and practices of school leadership training. A one sample t-test statistics is $t=-8.41$ with a mean value of 1.62 there was statistically significant difference among the respondents concerning the gap between the intention and practices of school leadership training. This implies that, all of the 
respondents have no better understanding in terms of the intension and practices of school leadership preparation.

Table 6: Trainees Perception towards the Content Consideration of the Program

\begin{tabular}{|l|r|r|r|r|r|}
\hline \multicolumn{7}{|c|}{ One-Sample Statistics } \\
\hline & \multicolumn{1}{|c|}{$\mathrm{N}$} & Mean & $\begin{array}{c}\text { Std. } \\
\text { Deviation }\end{array}$ & \multicolumn{1}{|c|}{$\begin{array}{c}\text { Sig. (2- } \\
\text { tailed) }\end{array}$} \\
\hline I found serious policy issues in the training program & 190 & 1.53 & .761 & -8.583 & .000 \\
\hline $\begin{array}{l}\text { I found that the training has made me a real } \\
\text { practitioner }\end{array}$ & 188 & 1.49 & .705 & -9.825 & .000 \\
\hline $\begin{array}{l}\text { The training material considers the school rules \& } \\
\text { regulations }\end{array}$ & 190 & 1.49 & .733 & -9.604 & .000 \\
\hline I found the training as it is practice oriented & 190 & 1.54 & .732 & -8.723 & .000 \\
\hline
\end{tabular}

Concerning the relevance, appropriateness of and importance of the school leadership training program in public universities of Ethiopia with the specific focus on some universities is presented in Table 6.

Table 7: One-Sample Statistics

\begin{tabular}{|c|c|c|c|c|c|}
\hline & $\mathrm{N}$ & Mean & Std. Deviation & $\mathrm{t}$ & Sig. (2-tailed) \\
\hline Content & 188 & 1.5080 & .60242 & 11.199 & .000 \\
\hline
\end{tabular}

The t-test analysis was carried out to identify the significant difference among respondents with regard to the content of school leadership training program. Accordingly, the calculated t-test is 11.20 implying respondents were not able to agree or disagree on the content of school leadership training program with insignificant difference. The implication of this is that the respondents have little knowledge with regard to how the leadership training and development practices are going and how it is done. 
Table 8: Factors Affecting the Practice of School Leadership Training

\begin{tabular}{|l|r|r|r|r|r|r|}
\hline \multicolumn{7}{|c|}{ One-Sample Statistics } \\
\hline
\end{tabular}

In Table 8 respondents were asked to rank order the factors they assumed to affect the school leadership training program. Accordingly, 9 factors were presented for the respondents to rank order them the most critical factors to less critical factors. Hence, the outstanding factor was thinking of less value of the certificate earned from the program followed by the lack of interest from the trainees' side.

However, the infeasibility of the program to implement stood last (mean=1.94) in affecting the effectives of school leadership training program. Respondents were also reported that the scarcity of resources was not a critical problem in preparing and training school leaders.

Table 9: One-Sample Statistics

\begin{tabular}{|l|c|r|r|r|r|}
\hline & $\mathrm{N}$ & Mean & Std. Deviation & \multicolumn{1}{c|}{$\mathrm{t}$} & \multicolumn{1}{l|}{ Sig. (2-tailed) } \\
\hline Factors & 165 & 1.8339 & .46190 & -4.618 & .000 \\
\hline
\end{tabular}

In ranking the factors affecting the school leadership training program, t-test was made to see the opinion difference in ranking the factors. Accordingly, the calculated value is $(t=-4.62)$ showing the absence of significant difference among respondents in ranking the factors with their critical roles.

On the factors affecting the implementation of school leadership training program, there is no significant difference among the participants. All the participants held the understanding that of all the factors the least values attached to the certificate of training as the most critical factors. This means people did not value the training certificate and aspire for some other benefits. 


\section{Conclusion and Recommendations}

The ultimate aim of this study was to assess the practices and prospects of the current school leadership training program with special focus on some public universities. The findings of the study show that the current practice of school leadership preparation has a lot of promising aspects although there are a number of drawbacks at different levels including the trainees themselves.

Looking in to the background of the respondents, the majority of prospective school leaders or the current trainees were found to be males. The implication is that unless an alternative mechanism is put in place it will be a challenge to maintain the balance between the two sexes in the education sector in general and in schools in particular. On the other hand, the trainees were at right and appropriate age level for carrying out the given responsibility implying working on other human resources aspects than the personal information.

Concerning the importance of the program many of the respondents were not able to agree or disagree. The implication is that there is little understanding on the side of the trainees on the why of the program. This little understanding might lead to weakness in performance unless awareness creation program is designed and implemented by the universities and education offices at different levels. The rationale is that without clear understanding better performance might not be attained.

On the intention and the actual practices of the program, the result of the analysis shown that there is no significant difference among the trainees in replying that there is no strong relation between the intention of the training program and the actual practices. The intention of the program is to create a strong school leadership whereby they can contribute for the improvement of school performance. Actually, the practice was found to differ from the primary intention of the program and hence an action is needed to align the primary intention of the program with the actual practices on the training.

On the perception with regard to the relevance of the content of the program to the current school environment, respondents were asked to express their views and opinion. Accordingly, the results have shown that trainees held the opinion that the program well addressed the education policy issues and aspects in Ethiopia. Moreover, the program was also perceived to have the potential to produce practitioners in areas of school leadership by creation better awareness on rues and regulation of the university and schools.

However, the results have shown that trainees have the understanding that the program is less practices oriented and totally limited to classroom practices. Accordingly, they expressed that the school leadership program in place is less practice oriented. This could be due to the training modality that it did not allow the training institutions to attach

With regard to factors affecting the implementation of school leadership training program in public universities, it varies from the very serious to the least serious ones in terms of their perceived effect. The values attached to the certificate earned from the completion of the training program and the lack of interest from the side of the trainees stood first and second in terms of affecting the effectiveness of the training program. From this, it is recommended that there has to be some benefits attached to the completion of the program and earning of the certificates. 


\section{References}

Dawit, M. (2008). Reflection on the teacher education system overhaul (TESO) program in Ethiopia. Promises, Pitfalls, Propositions, Addis Ababa.

Ghelawdewos, A. (2015). Reflection on the development of higher education in Ethiopia. Institute for Education and Development in Africa.

ILO (2012). A Handbook of Good Human Resource Management Practices in the Teaching Profession. Sectoral Activities Department, Geneva

Lemlem, T. (2010). Review of some recent literature: identifying factors that affect Ethiopia's education crisis. Ethiopian E-Journal for Research and Innovative Foresight, 2(2), 56-68.

Mulu, B. (2014). Factors affecting academic staff turnover intentions and the moderating effect of gender. International Journal of Research in Business Management, 2 (9), 57-70.

Mulu, N. (2012). Quality and quality assurance In Ethiopian higher education: Critical issues and practical implications. Printed by Ipskamp Drukkers, Enschede, The Netherlands.

Mutahaba (2009). Human resource management in African public sector: Current state and future direction: A tool for developing capacities for managing the human resource in Africa's public sector institutions.

Gorard, S., \& Taylor, C. (2004). Combining methods in educational and social research conducting educational research. McGraw-Hill Education (UK).

Teshome, W. (2015). Perceived competency of human resource managers in referral hospitals, Ethiopia. Global Journal of Management and Business Research; Administration and Management, Global Journal Inc., USA, 15 (8), 1-11.

World Bank (2008). Higher education finance and cost-sharing in Ethiopia. Ethiopia, Washionington, DC. World Bank 